\title{
Evaluation of temperature rise following the application of diode and ErCr:Ysgg lasers: an ex vivo study
}

\section{Purpose}

Erbium, chromium: yttrium, scandium, gallium, garnet (ErCr:Ysgg) lasers have been frequently used in oral surgical procedures and are almost seen as alternatives to diode lasers. The aim of this comparative study was to analyze in an animal model the thermal elevation induced by ErCr:Ysgg and diode lasers in soft tissue and bone.

\section{Materials and methods}

Thirty freshly dissected sheep mandibles containing bone and soft tissue were divided into 120 equal parts. Gallium-aluminum-arsenide (Ga-Al-As) diode laser $(\lambda=940 \mathrm{~nm})$ with 1, 2 and $5 \mathrm{~W}$ output powers and ErCr:Ysgg laser $(\lambda=2780 \mathrm{~nm})$ with $2.75,4.5$ and $6 \mathrm{~W}$ output powers were used on soft and bone tissues separately for 3 seconds with point application. Mean temperature values before and after application of the lasers were compared in soft tissue and bone.

\section{Results}

The minimum mean temperature value was observed with $2.75 \mathrm{~W}$ ErCr:Ysgg laser while irradiation with $5 \mathrm{~W}$ diode laser created the maximum values $(p<0.05)$.

\section{Conclusion}

ErCr:Ysgg laser $(\lambda=2780 \mathrm{~nm})$ with $2.75 \mathrm{~W}$ power generates low levels of heat compared to diode lasers and may provide safer surgery in soft and bone tissues without destructive effects of temperature increase.

Keywords: Bone; diode laser; ErCr:Ysgg lasers; soft tissue; temperature rise

\section{Introduction}

Laser devices are alternative surgical instruments which are frequently used in oral surgical procedures such as frenectomy, periodontal and peri-implant surgery, gingival surgery and excision of soft tissue tumors (1-5). They emit coherent and homogeneous light which shows reflection, absorption, transmission and scattering when applied on biological tissues. Absorbed energy is tolerated by the tissue or transforms into other forms of energy such as heat and photochemical reactions (6).

Laser light may induce thermal damage in the surrounding tissues both on the horizontal and vertical plain in the oral cavity $(1,7)$. Increased heat causes structural changes and retraction in biological tissues up to $600^{\circ} \mathrm{C}$. Protein denaturation and coagulation occurs when the temperature arises above $600^{\circ} \mathrm{C}$, while tissue carbonization and charring are observed between $900-1000^{\circ} \mathrm{C}$. Tissue ablation occurs when the temperature rises above $1000^{\circ} \mathrm{C}$. Thermal destruction of the surrounding tissues by the laser light may lead to delayed wound healing compared to scalpel incision (7). An ideal laser should maintain the thermal threshold in acceptable levels and should not provoke thermal damage to the surrounding tissues.

\author{
Alper Sindel ${ }^{1}$, \\ Ömür Dereci2, (1) \\ Mükerrem Hatipoğlư \\ Öznur Özalp', \\ Olgu Nur Dereci ${ }^{4}$, \\ Burak Kocabalkan', \\ Adnan Öztürk ${ }^{5}$ (])
}

ORCID IDs of the authors: A.S. 0000-0001-8760-5958; Ö.D. 0000-0003-0468-1096; M.H. 0000-0003-4698-292X; Ö.Ö. 0000-0003-4350-1975; O.N.D. 0000-0002-1352-3711; B.K. 0000-0002-7717-3765; A.Ö. 0000-0002-1660-3733

'Department of Oral and Maxillofacial Surgery, Akdeniz University, Faculty of Dentistry, Antalya, Turkey

${ }^{2}$ Department of Oral and Maxillofacial Surgery, Eskişehir Osmangazi University, Faculty of Dentistry, Eskişehir, Turkey

${ }^{3}$ Department of Periodontology, Akdeniz University, Faculty of Dentistry, Antalya, Turkey

${ }^{4}$ Department of Public Health, Gazi University, Faculty of Medicine, Ankara, Turkey

${ }^{5}$ Department of Oral and Maxillofacial Surgery, Ankara University, Faculty of Dentistry, Ankara, Turkey

This study was previously presented as an oral presentation at TAOMS $24^{\text {th }}$ International Congress held in Bodrum, Muğla, Turkey on May 25, 2017.

Corresponding Author: Alper Sindel E-mail: dtalpersindel@gmail.com

Received: 06 July 2017 Revised: 28 September 2017 Accepted: 11 October 2017 DOI: $10.26650 /$ eor.2018.479 
Diode and erbium, chromium: yttrium, scandium, gallium, garnet (ErCr:Ysgg) lasers are two different types of lasers which produce light in different wavelengths. It is reported that diode laser light induces thermal changes in the surrounding area of the related application site $(8,9)$. ErCr:Ysgg lasers have been frequently used in oral surgical procedures and are almost seen as alternative to diode lasers $(9,10)$. ErCr:Ysgg lasers are used with water irrigation and considered to create heat generation in decreased levels by the help of the irrigation system $(10,11)$. Although histologic effects of diode and ErCr:Ysgg lasers are well-known, the heat generation after the application of diode and ErCr:Ysgg lasers has not been studied yet. The aim of this study was to compare the thermal changes after the application of ErCr:Ysgg and diode lasers in soft tissue and bone. The null hypothesis tested in this research is that there is no difference in the thermal changes occurring in the soft tissue and bone after the application of ErCr:Ysgg and diode lasers.

\section{Materials and methods}

\section{Study design}

Ethical approval was obtained from the local Animal Research Ethics Committee of the Akdeniz University (Antalya, Turkey) with approval number 556. Thirty freshly dissected sheep mandibles with residual soft tissues of muscles were divided into 120 equal parts and were placed into a water tank of which the temperature was adjusted to $35-37^{\circ} \mathrm{C}$ using a glass heater (Kenis K-366; Kenis, Osaka, Japan) and hygro-thermometer (Nimomed; Estar Electronic Co., Ltd., Changshan, China) (Figure 1) to simulate oral tissues at body temperature. Each specimen was obtained from the body of the mandibles and comprised at least $5 \mathrm{~mm}$ soft tissue. Laser applications were performed in 6 hours after the specimens were obtained in order to maximize the usability of specimens. Diode and ErCr:Ysgg lasers with 3 different energy outputs were performed during 3 seconds on soft and bone tissue of the specimens separately. Gallium-aluminum-arsenide (Ga-Al-As) diode laser (Epic; Biolase, Irvine, CA, USA) $(\Lambda=940 \mathrm{~nm}$ ) with $300 \mu \mathrm{m}$ fibre tip was used with 1,2 and $5 \mathrm{~W}$ output powers. ErCr:Ysgg laser $(\Lambda=2780 \mathrm{~nm})$ (Waterlase iPlus; Biolase, Irvine, CA, USA) was used with G4 fire tip (600 $\mu$ m diameter, $6 \mathrm{~mm}$ length) at 2.75, 4.5 and $6 \mathrm{~W}$ with a $40 \%$ water and $20 \%$ air spray during irradiation. The temperature of irrigation water was adjusted to $25^{\circ} \mathrm{C}$, according to the manufacturers' specifications. The dispersion of the specimens to the groups were shown in Table 1.

Probe of the thermocouple device (Keitley 2000 Digital Multimeter; Keithley Instruments, Inc., Cleveland, OH, USA) was inserted into the bone and soft tissue separetely at a distance of $3 \mathrm{~mm}$ to the laser application point (Figure 2). Each measurement was repeated 3 times before and immediately after the application of lasers and a mean value was calculated for all groups.

\section{Statistical analysis}

Statistical analysis was performed using IBM Statistical Package for the Social Sciences (SPSS) Statistics version 22 (SPSS IBM
Corp.; Armonk, NY, USA). The normality of distribution and the homogeneity of variances of the sample were established using visual inspection of histograms, QQ-plots, box plots and Shapiro-Wilk's test $(p<0.05)$, respectively. The comparison of the mean temperature values of specimens before and after the application of diode and ErCr:Ysgg lasers was carried out by using t-test. The analysis of the significance between the mean temperature values of bone and soft tissues before and after the application of lasers was also performed with t-test. ANOVA was performed for comparison of the mean temperature values of specimens before and after the application of different power settings (1, 2, 5, 2.75, 4.5 and $6 \mathrm{~W})$ of diode and ErCr:Ysgg lasers. Sidak's correction test was utilized for the post-hoc analysis. One-way multivariate analysis of variance (MANOVA) was also performed for determining whether the mean temperature was different between bone and soft tissue, laser types and several power settings. Post-hoc analysis was carried out with Bonferroni's correction test. The confidence interval was set to $95 \%$ and $\mathrm{p}<0.05$ was considered significant.

\section{Results}

No statistically significant difference was observed between initial temperature measurements before the application of each laser. The temperature of specimens irradiated with diode laser was significantly increased compared to specimens irradiated with ErCr:Ysgg laser $(p<0.05)$ (Table 2). There was no statistically significant difference between the mean temperature values of bone and soft tissues before and after laser application (Table 3).

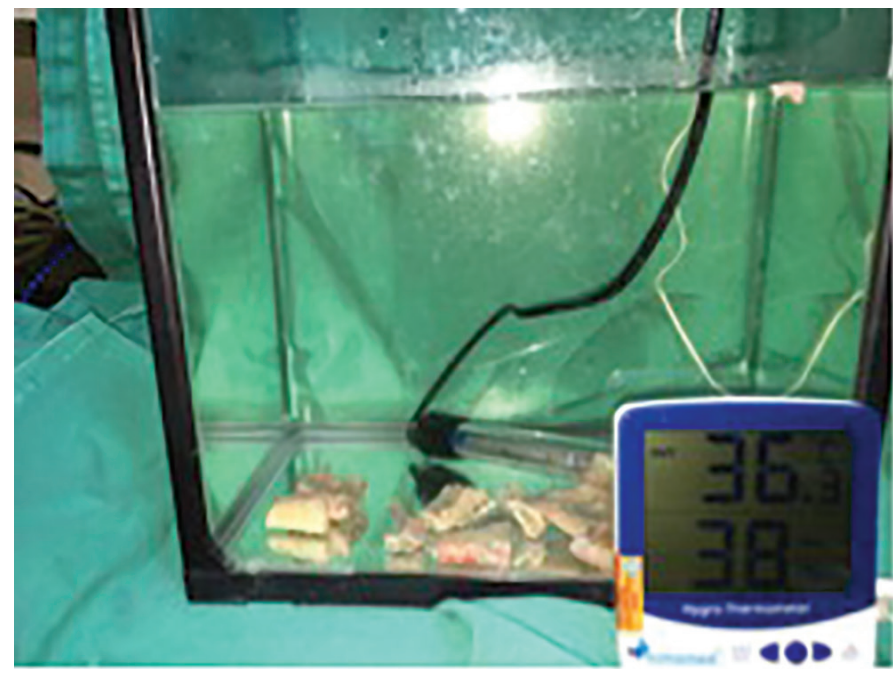

Figure 1. A thermal controller was used to adjust the temperature of the water close to the body temperature.

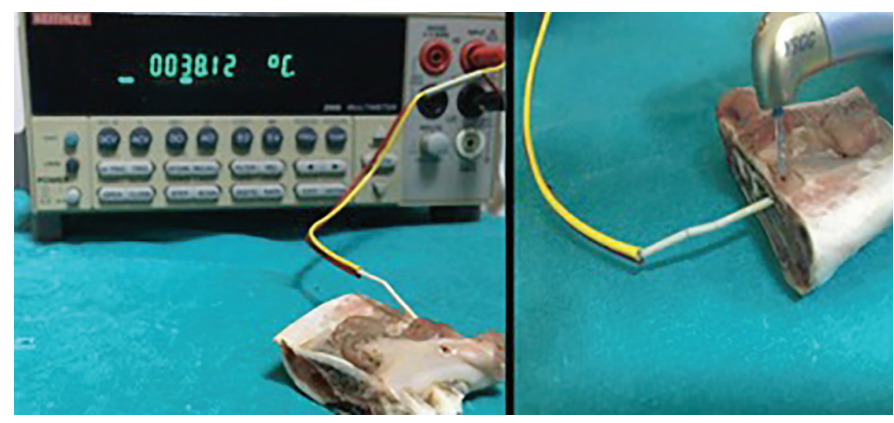

Figure 2. $3 \mathrm{~mm}$ distance was provided between thermocouple probe and laser application point. 
Table 1. Duration and power settings of the laser devices applied on specimens

\begin{tabular}{|c|c|c|c|}
\hline Application Period & Laser Device & Tissue & Power \\
\hline \multirow[t]{12}{*}{3 seconds } & Diode $(\mathrm{N}=60)$ & Soft Tissue $(\mathrm{N}=30)$ & $1 \mathrm{~W}(\mathrm{~N}=10)$ \\
\hline & & & $2 \mathrm{~W}(\mathrm{~N}=10)$ \\
\hline & & & $5 \mathrm{~W}(\mathrm{~N}=10)$ \\
\hline & & Bone $(\mathrm{N}=30)$ & $1 \mathrm{~W}(\mathrm{~N}=10)$ \\
\hline & & & $2 \mathrm{~W}(\mathrm{~N}=10)$ \\
\hline & & & $5 \mathrm{~W}(\mathrm{~N}=10)$ \\
\hline & ErCr:Ysgg (N=60) & Soft Tissue $(\mathrm{N}=30)$ & $2.75 \mathrm{~W}(\mathrm{~N}=10)$ \\
\hline & & & $4.5 \mathrm{~W}(\mathrm{~N}=10)$ \\
\hline & & & $6 \mathrm{~W}(\mathrm{~N}=10)$ \\
\hline & & Bone $(\mathrm{N}=30)$ & $2.75 \mathrm{~W}(\mathrm{~N}=10)$ \\
\hline & & & $4.5 \mathrm{~W}(\mathrm{~N}=10)$ \\
\hline & & & $6 \mathrm{~W}(\mathrm{~N}=10)$ \\
\hline
\end{tabular}

N: sample size; W: watt

Table 2. Comparison of the mean temperature changes of diode and ErCr:Ysgg lasers before and after application

\begin{tabular}{lcccccc} 
Temperature & Tissue & N & Mean & SD & t & p \\
Initial & Bone & 60 & 37.26 & 0.89 & -0.42 & 0.68 \\
& Soft Tissue & 60 & 37.33 & 0.80 & 0.94 & 0.35 \\
Post-application & Bone & 60 & 40.51 & 40.04 & 2.76 & 1.12 \\
\hline Difference & Soft Tissue & 60 & 3.25 & 2.68 & 0.26 \\
\hline
\end{tabular}

$\mathrm{p}<0.05$ was determined as statistically significant: $\mathrm{p}$ value in bold emphasis shows that there was statistically significant difference between diode and Er, Cr:YSGG laser after the application; SD: standard deviation

Table 3. Comparison of the mean temperature values of bone and soft tissues before and after the laser application

\begin{tabular}{|c|c|c|c|c|c|c|}
\hline Temperature & Laser & $\mathbf{N}$ & Mean & SD & $\mathbf{t}$ & $\mathbf{p}$ \\
\hline \multirow[t]{2}{*}{ Initial } & Diode & 60 & 37.43 & 0.74 & 1.69 & 0.09 \\
\hline & ErCr:Ysgg & 60 & 37.17 & 0.93 & & \\
\hline \multirow[t]{2}{*}{ Post-application } & Diode & 60 & 41.53 & 3.06 & 5.57 & 0.00 \\
\hline & ErCr:Ysgg & 60 & 39.03 & 1.64 & & \\
\hline \multirow[t]{2}{*}{ Difference } & Diode & 60 & 4.10 & 2.96 & 5.17 & 0.00 \\
\hline & ErCr:Ysgg & 60 & 1.86 & 1.57 & & \\
\hline
\end{tabular}

SD: standard deviation; $\mathrm{p}<0.05$ was determined as statistically significant

There was no statistically significant change in the mean temperature values between 6 different power settings of diode and ErCr:Ysgg lasers before the application ( $p>0.05)$. However, statistically significant difference was found between lasers after the application with different power settings $(p<0.05)$. Post-hoc test revealed that mean temperature value of 2.75 W ErCr:Ysgg laser is significantly decreased compared to other power settings $(p<0.05)$ (Table 4$)$. While mean temperature values of $1 \mathrm{~W}$ diode laser and $4.5 \mathrm{~W}$ ErCr:Ysgg laser were significantly increased compared to $2.75 \mathrm{~W}$ ErCr:Ysgg laser $(p<0.05)$, they were significantly decreased compared to 2 W diode laser, 5 W diode laser and 6 W ErCr:Ysgg laser $(p<0.05)$.
Mean temperature values of $2 \mathrm{~W}$ diode and $6 \mathrm{~W}$ ErCr:Ysgg lasers were significantly decreased compared to $5 \mathrm{~W}$ diode laser. Mean temperature values of $5 \mathrm{~W}$ diode laser was significantly increased compared to the mean values of remaining laser power parameters $(p<0.05)$ (Table 5$)$.

According to the MANOVA, the type of tissue and laser were found to have significant association with mean temperature difference on bone and soft tissue $\left(F_{L^{*} D}=19,91, p<0.05\right)$. Bonferroni correction test revealed that the application of diode laser generated significantly higher temperature difference on bone (4.21) and soft tissue (3.98) than the ErCr:Ysgg laser (1.44 for soft tissue and 2.28 for bone). Likewise, significant association was found between type of laser and power 
Table 4. The comparison of the mean temperature values before and after the application of diode and ErCr:Ysgg lasers with different power outputs

\begin{tabular}{|c|c|c|c|c|c|c|}
\hline Temperature & Power output & $\mathbf{N}$ & Mean & SD & $\mathbf{F}$ & $\mathbf{p}$ \\
\hline \multirow[t]{6}{*}{ Initial } & Diode 1W (1) & 20 & 37.32 & 0.70 & 0.87 & 0.50 \\
\hline & Diode 2W (2) & 20 & 37.48 & 0.81 & & \\
\hline & ErCr:Ysgg 2.75W (3) & 20 & 37.33 & 0.90 & & \\
\hline & ErCr:Ysgg 4.5W (4) & 20 & 37.10 & 0.96 & & \\
\hline & Diode 5W (5) & 20 & 37.48 & 0.73 & & \\
\hline & ErCr:Ysgg 6W (6) & 20 & 37.08 & 0.96 & & \\
\hline \multirow[t]{6}{*}{ Post-application } & Diode 1W (1) & 20 & $38.74^{\text {ad }}$ & 0.93 & 110.74 & 0.01 \\
\hline & Diode 2W (2) & 20 & $40.44^{\text {be }}$ & 1.06 & & \\
\hline & ErCr:Ysgg 2,75W (3) & 20 & $37.75^{\mathrm{ci}}$ & 0.89 & & \\
\hline & ErCr:Ysgg 4,5W (4) & 20 & $38.82^{\text {af }}$ & 1.24 & & \\
\hline & Diode 5W (5) & 20 & $45.41^{9}$ & 1.37 & & \\
\hline & ErCr:Ysgg 6W (6) & 20 & $40.53^{\text {bh }}$ & 1.38 & & \\
\hline \multirow[t]{6}{*}{ Difference } & Diode 1W (1) & 20 & 1.42 & 0.70 & 148.40 & 0.01 \\
\hline & Diode 2W (2) & 20 & 2.96 & 1.02 & & \\
\hline & ErCr:Ysgg 2,75W (3) & 20 & 0.42 & 0.54 & & \\
\hline & ErCr:Ysgg 4,5W (4) & 20 & 1.72 & 0.83 & & \\
\hline & Diode 5W (5) & 20 & 7.93 & 1.20 & & \\
\hline & ErCr:Ysgg 6W (6) & 20 & 3.45 & 1.33 & & \\
\hline
\end{tabular}

$\mathrm{p}<0.05$ was determined as statistically significant. Mean values haring a superscript letter are not significantly different; SD: standard deviation

Table 5. The comparison of the mean temperature values before and after diode and ErCr:Ysgg laser application with different power outputs

\begin{tabular}{|c|c|c|c|c|c|c|c|c|}
\hline Laser & Tissue & $\mathbf{w}$ & $\mathbf{n}$ & MD & SD & $\mathbf{F}_{\mathrm{L}^{*} \mathrm{D}}$ & $\mathbf{F}_{\mathbf{L}^{*} \mathrm{~W}}$ & $\mathbf{F}_{L^{*} D^{*} W}$ \\
\hline \multirow[t]{6}{*}{ Diode } & Bone & 1 & 10 & $1.11^{c}$ & 0.38 & 19.91 & 12.44 & 6.22 \\
\hline & & 2 & 10 & $3.51^{c}$ & 0.38 & & & \\
\hline & & 5 & 10 & $8.03^{a}$ & 1.41 & & & \\
\hline & Soft Tissue & 1 & 10 & $1.73^{c}$ & 0.81 & & & \\
\hline & & 2 & 10 & $2.41^{c}$ & 1.17 & & & \\
\hline & & 5 & 10 & $7.82^{\mathrm{a}}$ & 1.00 & & & \\
\hline \multirow[t]{6}{*}{ ErCr:Ysgg } & Bone & 2,75 & 10 & $0.35^{d}$ & 0.30 & & & \\
\hline & & 4,5 & 10 & $2.05^{c}$ & 0.71 & & & \\
\hline & & 6 & 10 & $4.45^{b}$ & 1.02 & & & \\
\hline & Soft Tissue & 2,75 & 10 & $0.49^{d}$ & 0.71 & & & \\
\hline & & 4,5 & 10 & $1.39^{c}$ & 0.84 & & & \\
\hline & & 6 & 10 & $2.45^{c}$ & 0.70 & & & \\
\hline
\end{tabular}

W: watt; $n$ : sample size; MD: mean difference; SD: standard deviation ${ }^{*} a>b>c>d$. a-b-c-d indicates the different groups according to the pairwise comparison

output $\left(F_{L^{*} W}=12,44, p<0.05\right)$. Post-hoc analysis revealed that ErCr:Ysgg at $2.75 \mathrm{~W}(0.42)$ created significantly lower temperature difference on bone and soft tissue compared to the other power outputs $(p<0.05)$. Diode laser at 5W (7.9) was found to have significantly higher temperature difference on bone and soft tissue compared to the other power outputs $(p<0.05)$. The mean temperature difference on bone and soft tissue was ranking between diode laser at $5 \mathrm{~W}$ (the highest), diode laser at 2W, ErCr:Ysgg laser at 6W, diode laser at 1W, $\mathrm{Er}, \mathrm{Cr}$ :YSGG laser at 4.5W and Er,Cr:YSGG laser at 2.75W (the lowest), respectively.
The type of tissue, laser and power output were found to have significant association with mean temperature difference on bone and soft tissue $\left(F_{L^{*} D^{*} W}=6.22, p<0.05\right)$ (Table 5). Post-hoc analysis revealed that diode laser at $5 \mathrm{~W}$ and Er,Cr:YSGG laser at $6 \mathrm{~W}$ created the highest temperature difference values among other groups. Diode laser at $5 \mathrm{~W}$ created significantly higher temperature difference on bone (8.03) and soft tissue (7.82) compared to the ErCr:Ysgg laser at 6W (4.45 in bone and 2.45 in soft tissue). Furthermore, ErCr:Ysgg laser at $2.75 \mathrm{~W}$ created the lowest temperature difference on both bone (0.35) and soft tissue (0.49) among the other groups. 


\section{Discussion}

Soft tissue interventions with appropriate laser are beneficial compared to other surgical instruments such as scalpel and electrocautery $(1,5,7)$. Diode lasers shows affinity to pigmented molecules in the affected tissue and mostly absorbed by haemoglobin, thus providing an advantage of suitability for soft tissue surgery $(1,8,9)$. However, ErCr:Ysgg laser with $2780 \mathrm{~nm}$ wavelength is exceedingly absorbed by water and hydroxiapatite and can be safely used in both bone and soft tissues $(2,3,9,12)$.

Biological effects of thermal increase during the laser application have been reported both for diode and ErCr:Ysgg lasers $(1,7,9)$. Cercadillo-Ibarguen et al. (10) reported that the microscopic extent of the thermal effect was lower after ErCr:Ysgg application compared to diode and $\mathrm{CO}_{2}$ lasers in their study in which they used porcine mucosal membranes as experimental model. Furthermore, it was also suggested that ErCr:Ysgg laser incision was comparable to scalpel incision in the histological examination and thermal destruction caused by laser excision did not affect proper histological diagnosis when applied with distance to the examined pathology $(10,13)$. Similarly, Rizoiu et al. (14) suggested that soft tissue wound healing after ErCr:Ysgg laser application was comparable with scalpel incision in the histopathological examination. A temperature increase above $10^{\circ} \mathrm{C}$ is considered harmful for biological tissues and may provoke irreversible tissue damage. Geminiani et al. (15) reported that diode laser irradiation may increase the temperature above $10^{\circ} \mathrm{C}$ after 10 seconds application. However, in the study of Leja et al. (16) in which they investigated thermal changes of dental implants after laser application in vitro, it was reported that $810 \mathrm{~nm}$ and $980 \mathrm{~nm}$ diode lasers with 1 W power output did not increase the temperature to critical threshold of $10^{\circ} \mathrm{C}$ in 60 seconds application time. However, CO2 and Er:YAG lasers increased the temperature over the critical threshold.

In the current study, the highest temperature generation on soft and bone tissue was observed with $5 \mathrm{~W}$ diode laser. Similarly, Merigo et al. (7) also reported that the highest temperature elevation in deep soft tissue was observed after $5 \mathrm{~W}$ diode laser application and the lowest temperature elevation was observed after Er:YAG laser application. In the present study, ErCr:Ysgg laser was used with concomittant air-water spray similar to Er:YAG lasers and showed lower temperature change compared to diode laser. When using high energy outputs in lasers, concomittant cooling may be beneficial to reduce the accumulated heat on biological structures (17).

As an interesting outcome of the study, $6 \mathrm{~W}$ ErCr:Ysgg laser showed less heat generation compared to $5 \mathrm{~W}$ diode laser, as the increase in the heat production did not correlate with the increase in the power output of the laser. Similarly, $1 \mathrm{~W}$ diode laser generated higher levels of heat compared to $2.75 \mathrm{~W}$ ErCr:Ysgg laser, indicating that heat generated with different laser types differed with different power outputs.

A previous study reported that ErCr:Ysgg laser was superior to diode laser with regards to the measurement of the damaged area adjacent to the laser incision (10). In the present study, following the application of both ErCr:Ysgg and diode lasers on soft and bone tissue, 2.75 W ErCr:Ysgg laser group showed the lowest heat generation among other ErCr:Ysgg and diode laser settings. Diode lasers should be used with special care due to their capability of penetrating deeper in the soft and bone tissues and causing irreversible damage (7, 15).

\section{Conclusion}

Present study revealed that diode laser $(\lambda=940 \mathrm{~nm})$ with $5 \mathrm{~W}$ power output produced elevated levels of temperature leading to the thermal damage to soft and bone tissues and ErCr:Ysgg laser $(\lambda=2780 \mathrm{~nm})$ with $2.75 \mathrm{~W}$ power generated low levels of heat compared to diode lasers. The findings of the current study support the idea that the use of ErCr:Ysgg laser with $2.75 \mathrm{~W}$ power may provide safer surgery regarding destructive effects due to temperature increase.

Ethics Committee Approval: Ethics committee approval was received for this study from the local Animal Research Ethics Commitee of the Akdeniz University (Antalya, Turkey) with approval number 556 .

Peer-review: Externally peer-reviewed.

Author Contributions: AS designed the study. ÖD, ÖÖ and BK generated the data. $\mathrm{MH}$ and OND participated in gathering the data for the study. AS and AÖ analyzed the data. ÖD and ÖÖ wrote the majority of the original draft. $\mathrm{AS}, \mathrm{MH}$ and $\mathrm{AOO}$ helped writing the paper. OND and BK collected the raw data of the study. All authors approved the final version of the paper.

Conflict of Interest: The authors have no conflicts of interest to declare.

Financial Disclosure: The authors declared that this study has received no financial support.

Türkçe öz: Diyot ve ErCr:Ysgg lazer uygulamalarını takiben sıcaklık artışının değerlendirilmesi: ex vivo çalışma. Amaç: Erbiyum, krom: itriyum-skandiyum-galyum-garnet (ErCr:Ysgg) lazerler oral cerrahi işlemlerde yaygın biçimde kullanılmakta olup, diyot lazerlere neredeyse alternatif olarak düşünülmektedir. Bu çalışmanın amacı, ErCr:Ysgg lazerler ve diyot lazerlerin kemik ve yumuşak dokuda meydana getirdikleri sıcaklık artışının bir hayvan modeli üzerinde karşılaştııılmasıdır. Gereç ve Yöntem: Otuz adet koyun mandibulası her biri kemik ve yumuşak doku içeren 120 eşit parçaya bölünmüştür. Yumuşak doku ve kemik üzerine ayrı ayrı olacak biçimde, 3 saniye süre ile 1, 2 ve $5 \mathrm{~W}$ çıkış güçlerinde galyum-aluminyum-arsenid (Ga-Al-As) diyot lazer $(\lambda=940 \mathrm{~nm}$ ) ve 2,75, 4,5 ve $6 \mathrm{~W}$ çıkış güçlerinde ErCr:Ysgg lazer $(\lambda=2780 \mathrm{~nm})$ uygulaması gerçekleştirilmiştir. Uygulama öncesi ve uygulamadan hemen sonraki ortalama sıcaklık değerleri karşılaştırılarak veriler analiz edilmiştir. Bulgular: En düşük ortalama sıcaklık değeri 2,75 W gücünde Er,Cr:YSGG lazer uygulamasında gözlenirken, 5 W gücünde diyot lazer uygulamasının en yüksek sıcaklık değerini oluşturduğu görülmüştür $(p<0,05)$. Sonuç: ErCr:Ysgg lazerin ( $\lambda=2780 \mathrm{~nm}$ ) 2,75 W güçte uygulanması, diyot lazerlerle kıyaslandığında daha düşük sıcaklık artışına neden olmakta ve sıcaklık artışının neden olabileceği yıkıcı etkiler bakımından, kemik ve yumuşak doku cerrahilerinde daha güvenli sonuçlar sağlayabileceği düşünülmektedir. Anahtar kelimeler: Diyot lazer; ErCr:Ysgg lazer; kemik; sıcaklık artışı;yumuşak doku. 


\section{References}

1. Beer F, Korpert W, Passow H, Steidler A, Meinl A, Buchmair AG, Moritz A. Reduction of collateral thermal impact of diode laser irradiation on soft tissue due to modified application parameters. Lasers Med Sci 2012; 27: 917-21. [CrossRef]

2. Hatipoglu M, Barutcigil C. Effects of erbium-and chromium-doped yttrium scandium gallium garnet and diode lasers on the surfaces of restorative dental materials: A scanning electron microscope study. Niger J Clin Pract 2015; 18: 213-20. [CrossRef]

3. Perussi LR, Pavone C, de Oliveira GJPL, Cerri PS, Marcantonio RAC. Effects of the er,cr:Ysgg laser on bone and soft tissue in a rat model. Lasers Med Sci 2012; 27: 95-102. [CrossRef]

4. Romeo U, Russo C, Palaia G, Lo Giudice R, Del Vecchio A, Visca P, Migliau G, De Biase A. Biopsy of different oral soft tissues lesions by ktp and diode laser: histological evaluation. Scientific World Journal 2014; 2014: DOI:10.1155/2014/761704 [CrossRef]

5. Ryu SW, Lee SH, Yoon HJ. A comparative histological and immunohistochemical study of wound healing following incision with a scalpel, co2 laser or er,cr:Ysgg laser in the guinea pig oral mucosa. Acta Odontol Scand 2012; 70: 448-54. [CrossRef]

6. Raymond J, Fonseca D, Robert D, Marciani D, Timothy A, Turvey D. Oral and maxillofacial surgery. Philadelphia: Saunders, 2009.

7. Merigo E, Clini F, Fornaini C, Oppici A, Paties C, Zangrandi A, Fontana M, Rocca JP, Meleti M, Manfredi M, Cella L, Vescovi P. Laser-assisted surgery with different wavelengths: A preliminary ex vivo study on thermal increase and histological evaluation. Lasers Med Sci 2013; 28: 497-504. [CrossRef]

8. Desiate A, Cantore S, Tullo D, Profeta G, Grassi FR, Ballini A. 980 $\mathrm{nm}$ diode lasers in oral and facial practice: Current state of the science and art. Int J Med Sci 2009; 6: 358-64. [CrossRef]
9. Jin JY, Lee $\mathrm{SH}$, Yoon HJ. A comparative study of wound healing following incision with a scalpel, diode laser or er,cr:Ysgg laser in guinea pig oral mucosa: A histological and immunohistochemical analysis. Acta Odontol Scand 2010; 68: 232-8. [CrossRef]

10. Cercadillo-Ibarguren I, Espana-Tost A, Arnabat-Dominguez J, Valmaseda-Castellon E, Berini-Aytes L, Gay-Escoda C. Histologic evaluation of thermal damage produced on soft tissues by $\mathrm{CO} 2$, er,cr:Ysgg and diode lasers. Med Oral Patol Cir Bucal 2010; 15: E912-8. [CrossRef]

11. Wang XG, Ishizaki NT, Suzuki N, Kimura Y, Matsumoto K. Morphological changes of bovine mandibular bone irradiated by er,cr : Ysgg laser: An in vitro study. J Clin Laser Med Surg 2002; 20: 245-50. [CrossRef]

12. Deppe $\mathrm{H}$, Horch HH. Laser applications in oral surgery and implant dentistry. Lasers Med Sci 2007; 22: 217-21. [CrossRef]

13. Eversole LR. Laser artifacts and diagnostic biopsy. Oral Surg Oral Med Oral Pathol Oral Radiol Endod 1997; 83: 639-40. [CrossRef]

14. Rizoiu IM, Eversole LR, Kimmel Al. Effects of an erbium, chromium: Yttrium, scandium, gallium, garnet laser on mucocutanous soft tissues. Oral Surg Oral Med Oral Pathol Oral Radiol Endod 1996; 82: 386-95. [CrossRef]

15. Geminiani A, Caton JG, Romanos GE. Temperature change during non-contact diode laser irradiation of implant surfaces. Lasers Med Sci 2012; 27: 339-42. [CrossRef]

16. Leja C, Geminiani A, Caton J, Romanos GE. Thermodynamic effects of laser irradiation of implants placed in bone: An in vitro study. Lasers Med Sci 2013; 28: 1435-40. [CrossRef]

17. Vescovi $P$, Merigo E, Fornaini C, Rocca JP, Nammour S. Thermal increase in the oral mucosa and in the jawbone during nd:Yag laser applications. Ex vivo study. Med Oral Patol Oral Cir Bucal 2012; 17: e697-704. [CrossRef] 